\title{
Scald risk in social housing can be reduced through thermostatic control system without increasing Legionella risk: a cluster randomised trial
}

P Edwards, Senior Lecturer, Faculty of Epidemiology and Population Health, London School of Hygiene \& Tropical Medicine, Keppel Street, London, UK WC1E 7HT.

MA Durand, Lecturer, Faculty of Public Health and Policy, London School of Hygiene \& Tropical Medicine, 15-17 Tavistock Place, London, UK WC1E 7HT.

M Hollister, Contract Manager, Department of Housing \& Adult Social Care, London Borough of Camden, London UK WC1H 9DF.

J Green, Reader, Faculty of Public Health and Policy, London School of Hygiene \& Tropical Medicine, 15-17 Tavistock Place, London, UK WC1E 7HT.

S Lutchmun, Public Health Strategist, Public Health Department, NHS Camden, St Pancras Hospital, London UK NW1 OPE.

A Kessel, Honorary Professor, Department of Social and Environmental Health Research, London School of Hygiene \& Tropical Medicine, 15-17 Tavistock Place, London, UK WC1E 7HT.

I Roberts, Professor, Faculty of Epidemiology and Population Health, London School of Hygiene \& Tropical Medicine, Keppel Street, London, UK WC1E 7HT.

\section{Correspondence to:}

Dr Phil Edwards, Room 136, NPHIR, Faculty of Epidemiology and Population Health London School of Hygiene \& Tropical Medicine, Keppel Street, London WC1E 7HT.

phil.edwards@LSHTM.ac.uk

Phone: $+44(0) 2079588112$

Fax: +44 (0)20 72994663 
The Corresponding Author has the right to grant on behalf of all authors and does grant on behalf of all authors, an exclusive licence (or non exclusive for government employees) on a worldwide basis to the BMJ Publishing Group Ltd and its Licensees to permit this article (if accepted) to be published in Archives of Disease in Childhood editions and any other BMJPGL products to exploit all subsidiary rights, as set out in our licence:

http://group.bmj.com/products/journals/instructions-for- authors/licence-forms.

3,156 words 


\section{ABSTRACT}

Objective: To quantify the effects of a thermostatic control system in social (public) housing on the prevalence of dangerous $\left(>60^{\circ} \mathrm{C}\right)$ water temperatures and on fuel consumption.

Design: Pair-matched double-blind cluster randomised controlled trial.

Setting: Social housing in a deprived inner-London borough.

Participants: 150 households recruited as clusters from 22 social housing estates. Four small estates were combined into two clusters (resulting in a total of 10 pairs of clusters).

Intervention: Social housing estate boiler houses were randomised to a thermostatic control sterilisation programme (heating water to $65^{\circ} \mathrm{C}$ during 00:00-06:00 hrs and to $50^{\circ} \mathrm{C}$ from $06: 00-$ 00:00 hrs daily) or to standard control (constant temperature $65^{\circ} \mathrm{C}$ ).

Main outcome measures: Water temperature over $60^{\circ} \mathrm{C}$ ('dangerous') after running taps for 1 minute and daily fuel consumption (cubic feet of gas).

Results: 10 clusters ( 80 households) were allocated to the sterilisation programme and 10 clusters ( 70 households) to control, of which 73 and 67 households, respectively, were analysed. Prevalence of dangerous $\left(>60^{\circ} \mathrm{C}\right)$ hot water temperatures at 1 minute was significantly reduced with the sterilisation programme (mean of cluster prevalence $1 \%$ in sterilisation programme group vs. $34 \%$ in control group; absolute difference $33 \%, 95 \% \mathrm{Cl} 12 \%$ to $54 \%$; $p=0.006$ ). Prevalence of high $\left(>55^{\circ} \mathrm{C}\right)$ hot water temperatures at 1 minute was significantly reduced $(31 \%$ sterilisation vs. $59 \%$ control; absolute difference $28 \%, 95 \% \mathrm{Cl} 9 \%$ to $47 \%$; $\mathrm{p}=0.009$ ). Gas consumption per day reduced more in the control group than in the sterilisation programme group, although not statistically significantly $(p=0.125)$.

Conclusions: The thermostatic control with daily sterilisation was effective in capping hot water temperatures and therefore reduced scald risk. Although expected to save energy, fuel consumption was increased relative to the control group.

Trial registration: ClinicalTrials.gov ID: NCT00874692

Keywords: Wounds and Injuries, Socioeconomic Factors, Legionella. 


\section{INTRODUCTION}

Hot tap water can be dangerous for children and the elderly.[1-3] Around 400 children are hospitalised each year in England for the treatment of scalds caused by hot tap water.[1] For every child admitted, many more receive treatment as outpatients.[2] The scarring caused by scalds can cause disfigurement and the costs to the NHS can be considerable.

Young children are at particular risk of being scalded by hot water because their skin is thinner and may be scalded in a shorter time and at lower temperatures. [4] At $60^{\circ} \mathrm{C}$ water will cause a full-thickness burn in 1 second in a child compared to 5 seconds in an adult.[5] At $55^{\circ} \mathrm{C}$ water can take under 1 minute to cause a major burn, but at $50^{\circ} \mathrm{C}$ water will take 5 minutes to cause a major burn.[6] Tap water scalds tend to occur in baths that have just been filled, or when a child who is already in a bath turns on the hot water tap.[7] These scalds tend to be more severe because the child is typically exposed to the water as it pours directly from the tap, or is partly immersed in hot water. The elderly are at particular risk of hot tap water scalds because they have slower reaction times and other physical impairments associated with aging.[8]

Almost four million families in England live in social housing (public housing rented by a local authority or housing association).[9] Over 30\% of these include people aged over 65 years and $17 \%$ households are lone parents with dependent children. Many of these households do not have individual boilers,[9] but are supplied with hot water from a central boiler house. These boilers are often set to heat water to temperatures greater than $60^{\circ} \mathrm{C}$ in order to kill Legionella.[10] However, whilst a high temperature may reduce the risk of Legionella, it increases the risk of scalds.

Legionnaires' disease is caused by a bacterium (Legionella) that can live and breed in hot and cold water systems at temperatures between $20^{\circ} \mathrm{C}$ and $45^{\circ} \mathrm{C}$. At water temperatures above $50^{\circ} \mathrm{C}$ the bacterium is killed.[10,11] The time taken to kill Legionella diminishes as water temperature increases. At $50^{\circ} \mathrm{C}$ it takes $2 \mathrm{hrs}$ to kill $90 \%$ of Legionella, at $60^{\circ} \mathrm{C}$ it takes 2 minutes, and over $70^{\circ} \mathrm{C}$ all Legionella are killed in seconds. $[12,13]$ Under $20^{\circ} \mathrm{C}$ Legionella are dormant. It is recommended that hot water is stored at $60^{\circ} \mathrm{C}$ and distributed so that within 1 minute of turning on a hot water tap the temperature reaches at least $50^{\circ} \mathrm{C}$, and that within 2 minutes of turning on a cold water tap the water temperature is less than $20^{\circ} \mathrm{C}$.[10, 11] 
Evidence from the USA suggests that setting a maximum storage temperature of $50^{\circ} \mathrm{C}$ can lead to fewer scalds with no discernible increase in Legionella infections.[14] Interventions that can deliver hot water to residents in social housing at safer temperatures whilst ensuring that the water system remains protected against Legionella have the potential to simultaneously reduce energy consumption, greenhouse gas emissions, fuel costs and the risk of scalds. In addition to contributing to targets for sustainable consumption, this could also provide direct benefits to residents if any energy savings made can be passed on to them through reductions in fuel bills.

In 2007 the Department of Housing and Adult Social Care of the London Borough of Camden began installation of boiler management systems throughout their social and sheltered housing. These thermostatic control systems aim to achieve optimal boiler-firing patterns for specific building and temperature requirements. A sterilisation programme was developed as an intervention that would regulate boiler-firing to heat water to a temperature sufficient to kill Legionella during the night, when scald risk is lowest, and to lower the temperature to a safer level during the day. We conducted a cluster randomised controlled trial to quantify change in prevalence of households with water temperatures exceeding $60^{\circ} \mathrm{C}$, and change in average daily fuel consumption, from introducing the thermostatic control sterilisation programme.

\section{METHODS}

\section{Study design and participants}

The cluster randomised controlled trial was undertaken in 22 social housing estates in Camden, a deprived inner-London borough. Estate boiler houses were pair-matched according to whether they supplied sheltered housing for the elderly or residential housing, and also by whether they supplied residences with or without individual hot water immersion cylinders. This matching was to ensure comparability of intervention and control groups with respect to factors expected to be associated with water temperature control. Four boiler houses serving smaller social housing estates were combined into two clusters of two boiler houses each (resulting in a total of 10 pairs of clusters) to create matched clusters of approximately equal size.

\section{Randomisation}

The estates were randomly allocated to thermostatic control or to control by an independent researcher (who used a coin toss to determine allocation and who remained blind to the names and geographical locations of the estates).

\section{Interventions}


The estates were randomly allocated to a thermostatic control sterilisation programme that aimed to heat water to $65^{\circ} \mathrm{C}$ during $00: 00-06: 00 \mathrm{hrs}$ and then to $50^{\circ} \mathrm{C}$ from $06: 00-00: 00 \mathrm{hrs}$ daily, or to standard control aiming for a constant temperature at $65^{\circ} \mathrm{C}$ (these temperatures were chosen due to local concerns about Legionella).

\section{Objectives}

The study objectives were to quantify the effects of a thermostatic control system in social (public) housing on the prevalence of dangerous $\left(>60^{\circ} \mathrm{C}\right)$ water temperatures and on fuel consumption in estates.

\section{Outcome measures}

The primary outcomes were water temperature $>60^{\circ} \mathrm{C}$ ('dangerous') and $>55^{\circ} \mathrm{C}$ ('high'), and daily fuel consumption (cubic feet of gas). Water temperature was measured first after running bath taps for 1 minute, and then again when the maximum temperature was attained. Secondary outcomes were cold water temperature at 2 minutes, and acceptability of hot water temperatures (residents were asked "How would you like your hot water?" to which they could respond that they prefer the temperature the same, hotter, colder, or didn't mind). Data were collected by the project manager and research assistants who remained blind to allocation of estates. Water temperatures were measured in degrees Celsius $\left({ }^{\circ} \mathrm{C}\right)$ using an Anton ATM 200 electronic thermometer. Sink taps were used where baths were inaccessible or not present (i.e. shower only). Participants were given a $f 5$ supermarket voucher as a small recompense and were informed that researchers would return to measure the water temperature again in a few weeks. At follow-up participants were contacted in the same order as at baseline. If participants were not at home after three attempts to contact them, they were replaced with a neighbouring household, chosen at random. Fuel consumption was measured by recording the gas meter readings at each boiler house at baseline, intervention and at end of follow-up.

\section{Sample size}

We estimated that temperature measurements from 150 households (average 7 households from 22 clusters) would provide $90 \%$ power at a $5 \%$ significance level to detect a change from $40 \%$ to $10 \%$ in prevalence of households with dangerous water temperatures, assuming a coefficient of variation (i.e. between-cluster variation in prevalence divided by mean cluster prevalence) equal to 0.5 .[15] To achieve the target sample size a $10 \%$ sample of households was selected from each housing estate. The purpose of this approach was to include variation in outcomes that may be due to height of buildings, or due to distance of each household from the central boiler house. For example, in a six storey block comprising 120 flats, we randomly recruited two households from each floor to give 12 households (i.e. a $10 \%$ sample). 


\section{Statistical analysis}

For hot water temperatures we calculated the absolute difference in prevalence of water $>60^{\circ} \mathrm{C}$ ('dangerous') and $>55^{\circ} \mathrm{C}$ ('high') in each pair of clusters. We calculated the arithmetic mean of these differences in prevalence with a 95\% confidence interval using the t-distribution with 9 degrees of freedom. For each cluster we calculated the proportionate change in gas consumption (cubic feet per day) after the date of intervention. We then calculated the ratio of these proportionate change figures for each pair of clusters. We calculated the geometric mean (with 95\% $\mathrm{Cl}$ ) of these ratios (allowing for a positive skew in their distribution). For cold water temperatures we calculated the difference in the mean temperature in each cluster, and then calculated the arithmetic mean (with $95 \% \mathrm{Cl}$ ) of these differences. For acceptability of hot water temperatures we calculated the difference in prevalence of participants who said that they liked their water the same as on the day of measurement, or that they didn't mind. We calculated the arithmetic mean (with $95 \% \mathrm{Cl}$ ) of these differences in prevalence. Evidence against the null hypothesis of no effect of the intervention was assessed using a paired t-test on the differences (or ratios) for the 10 pairs of clusters,[15] and using the non-parametric Wilcoxon matched-pairs signed-ranks test. The two clusters that each comprised two boiler houses were analysed as single clusters when estimating the effect of the intervention. A complete case analysis was undertaken and a second analysis that included the replacement households.

This study is registered as ClinicalTrials.gov ID: NCT00874692. Ethical approval for the study was obtained from the London School of Hygiene \& Tropical Medicine Research Ethics Committee.

\section{RESULTS}

Figure 1 shows the trial profile. Recruitment of residents and baseline data collection from 150 households was conducted during April and May 2009. The sterilisation programme was activated by Camden Department of Housing and Adult Social Care on 21 May 2009. Follow-up data were collected during June and July 2009, and were successfully obtained from 140 (93\%) households.

[Figure 1 here]

The random allocation of clusters to the sterilisation programme and control groups achieved reasonably comparable distributions of baseline water temperatures (table 1). The average hot water temperature at 1 minute in the 150 households was $55.2^{\circ} \mathrm{C}$ and the average maximum 
temperature attained was $57.7^{\circ} \mathrm{C}$. The maximum temperature recorded in a single household was $81.4^{\circ} \mathrm{C}$. The average cold water temperature at 2 minutes was $17.8^{\circ} \mathrm{C}$.

Table 1 Hot and cold water measurements in households at baseline $\left({ }^{\circ} \mathrm{C}\right)$

\begin{tabular}{rrrrrrrrr}
\hline & \multicolumn{3}{c}{ Sterilisation (80 households) } & \multicolumn{4}{c}{ Control (70 households) } \\
& mean & SD & $\min$ & $\max$ & mean & SD & min & max \\
\hline Hot $(1 \mathrm{~m})$ & 55.7 & 10.2 & 23.5 & 71.9 & 54.7 & 11.0 & 24.3 & 81.2 \\
Hot (maximum) & 57.9 & 9.2 & 23.5 & 72.3 & 57.4 & 10.1 & 34.6 & 81.4 \\
Cold $(2 \mathrm{~m})$ & 19.0 & 4.8 & 12.2 & 33.4 & 16.6 & 4.3 & 11.1 & 30.5 \\
\hline
\end{tabular}

Table 2 Hot and cold water measurements in households at follow-up $\left({ }^{\circ} \mathrm{C}\right)$

\begin{tabular}{rrrrrrrrr}
\hline & \multicolumn{3}{c}{ Sterilisation (73 households) } & \multicolumn{4}{c}{ Control (67 households) } \\
& mean & SD & $\min$ & $\max$ & mean & SD & min & max \\
\hline Hot $(1 \mathrm{~m})$ & 52.81 & 4.80 & 34.5 & 62.0 & 57.72 & 9.48 & 35.4 & 76.8 \\
Hot (maximum) & 53.95 & 3.96 & 38.5 & 62.5 & 59.27 & 9.49 & 36.9 & 78.5 \\
Cold $(2 \mathrm{~m})$ & 22.37 & 2.68 & 18.8 & 29.6 & 21.85 & 3.56 & 16.8 & 31.7 \\
\hline
\end{tabular}

[Figure 2 here]

Figure 2 shows the changes in temperature between baseline and follow-up within households. Higher temperatures at baseline were associated with higher temperatures at follow-up. The spread of temperatures was reduced by the intervention, where standard deviations of the hot water temperatures in the sterilisation group were half those in the control group (table 2).

At follow-up, one (1\%) household in the sterilisation programme group had water temperature over $60^{\circ} \mathrm{C}$ at 1 minute compared with $23(34 \%)$ households in the control group (table 3). The sterilisation programme achieved an absolute reduction of 33\% (95\% confidence interval $12 \%$ to $54 \% ; p=0.006$; Wilcoxon signed-ranks test $p=0.011$ ) in the prevalence of 'dangerous' hot water temperatures at 1 minute compared with controls. There was also an absolute reduction of $28 \%$ (95\% Cl 9\% to 47\%; $p=0.009$; Wilcoxon signed-ranks test $p=0.008$ ) in prevalence of 'high' hot water temperatures at 1 minute. 
Table 3 Prevalence of temperatures $>60^{\circ} \mathrm{C}$ and $>55^{\circ} \mathrm{C}$ at 1 minute by intervention group

\begin{tabular}{|c|c|c|c|c|c|c|c|c|c|}
\hline \multirow[b]{2}{*}{ Matched pair } & \multirow[b]{2}{*}{$\mathrm{n}$} & \multicolumn{3}{|c|}{ Sterilisation } & \multicolumn{4}{|c|}{ Control } & \multirow{2}{*}{$\begin{array}{r}\text { Absolute } \\
\text { difference }\end{array}$} \\
\hline & & $>60^{\circ} \mathrm{C}$ & Prevalence & SD & $\mathrm{n}$ & $>60^{\circ} \mathrm{C}$ & Prevalence & SD & \\
\hline 1 & 2 & 0 & 0.000 & 0.000 & 3 & 1 & 0.333 & 0.577 & -0.333 \\
\hline 2 & 3 & 0 & 0.000 & 0.000 & 3 & 2 & 0.667 & 0.577 & -0.667 \\
\hline 3 & 22 & 0 & 0.000 & 0.000 & 10 & 0 & 0.000 & 0.000 & 0.000 \\
\hline 4 & 5 & 0 & 0.000 & 0.000 & 5 & 0 & 0.000 & 0.000 & 0.000 \\
\hline 5 & 8 & 0 & 0.000 & 0.000 & 7 & 4 & 0.571 & 0.535 & -0.571 \\
\hline 6 & 11 & 0 & 0.000 & 0.000 & 17 & 8 & 0.471 & 0.514 & -0.471 \\
\hline 7 & 8 & 1 & 0.125 & 0.354 & 7 & 1 & 0.143 & 0.378 & -0.018 \\
\hline 8 & 7 & 0 & 0.000 & 0.000 & 9 & 5 & 0.556 & 0.527 & -0.556 \\
\hline 9 & 3 & 0 & 0.000 & 0.000 & 3 & 0 & 0.000 & 0.000 & 0.000 \\
\hline 10 & 4 & 0 & 0.000 & 0.000 & 3 & 2 & 0.667 & 0.577 & -0.667 \\
\hline Overall & 73 & 1 & & & 67 & 23 & & & \\
\hline $\begin{array}{r}\text { Mean cluster } \\
\text { prevalence }\end{array}$ & & & 0.013 & & & & 0.341 & & $\begin{array}{r}-0.328 \\
(-0.539 \text { to }-0.118) \\
\end{array}$ \\
\hline Matched pair & $\mathrm{n}$ & $>55^{\circ} \mathrm{C}$ & Prevalence & SD & $\mathrm{n}$ & $>55^{\circ} \mathrm{C}$ & Prevalence & SD & \\
\hline 1 & 2 & 1 & 0.500 & 0.707 & 3 & 2 & 0.667 & 0.577 & -0.167 \\
\hline 2 & 3 & 0 & 0.000 & 0.000 & 3 & 2 & 0.667 & 0.577 & -0.667 \\
\hline 3 & 22 & 12 & 0.545 & 0.510 & 10 & 7 & 0.700 & 0.483 & -0.155 \\
\hline 4 & 5 & 0 & 0.000 & 0.000 & 5 & 0 & 0.000 & 0.000 & 0.000 \\
\hline 5 & 8 & 2 & 0.250 & 0.463 & 7 & 5 & 0.714 & 0.488 & -0.464 \\
\hline 6 & 11 & 5 & 0.455 & 0.522 & 17 & 13 & 0.765 & 0.437 & -0.310 \\
\hline 7 & 8 & 6 & 0.750 & 0.463 & 7 & 6 & 0.857 & 0.378 & -0.107 \\
\hline 8 & 7 & 1 & 0.143 & 0.378 & 9 & 8 & 0.889 & 0.333 & -0.746 \\
\hline 9 & 3 & 0 & 0.000 & 0.000 & 3 & 0 & 0.000 & 0.000 & 0.000 \\
\hline 10 & 4 & 2 & 0.500 & 0.577 & 3 & 2 & 0.667 & 0.577 & -0.167 \\
\hline Overall & 73 & 29 & & & 67 & 45 & & & \\
\hline $\begin{array}{r}\text { Mean cluster } \\
\text { prevalence }\end{array}$ & & & 0.314 & & & & 0.593 & & $\begin{array}{r}-0.278 \\
(-0.089 \text { to }-0.467) \\
\end{array}$ \\
\hline
\end{tabular}

At follow-up, one (1\%) household in the sterilisation programme group had maximum water temperature over $60^{\circ} \mathrm{C}$ compared with $27(40 \%)$ households in the control group (matched pairs data not shown). The sterilisation programme achieved an absolute reduction of $37 \%(95 \% \mathrm{Cl}$ $15 \%$ to $59 \% ; p=0.004$ ) in prevalence of 'dangerous' maximum temperatures, and an absolute reduction of $27 \%$ ( $95 \% \mathrm{Cl} 7 \%$ to $47 \%$; $p=0.013$ ) in prevalence of 'high' maximum temperatures.

The mean temperature at 1 minute in the sterilisation clusters was on average $3.8^{\circ} \mathrm{C}(95 \% \mathrm{Cl}$ $1.4^{\circ} \mathrm{C}$ to $9.0^{\circ} \mathrm{C} ; \mathrm{p}=0.14$ ) lower than in the control clusters. The mean maximum temperature in the sterilisation clusters was on average $4.2^{\circ} \mathrm{C}\left(95 \% \mathrm{Cl}-1.3^{\circ} \mathrm{C}\right.$ to $\left.9.6^{\circ} \mathrm{C} ; \mathrm{p}=0.12\right)$ lower than in the control clusters (matched pairs data not shown). 
Gas meter readings were taken at each boiler house on 1 April 2009, 21 May 2009 and 31 July 2009. Between 1 April 2009 and 21 May 2009 total gas consumption in the sterilisation programme group was 392,404 cubic feet, and between 21 May 2009 and 31 July 2009 consumption was 354,747 cubic feet, an absolute reduction of 37,657 cubic feet ( $9.6 \%$ relative reduction). In the control group for these periods gas consumption was 344,591 cubic feet and 283,534 cubic feet respectively, an absolute reduction of 61,057 cubic feet $(17.7 \%$ relative reduction). Assuming a conversion factor of $2.013 \mathrm{~kg}$ of $\mathrm{CO}_{2}$ equivalents per cubic metre of natural gas the control group thus produced 1.334 tonnes of $\mathrm{CO}_{2}$ equivalents less than the sterilisation programme group over the period of the study (equivalent to around 7 tonnes of $\mathrm{CO}_{2}$ equivalents per year).

The mean proportionate change in gas consumption (cubic feet per day) after the date of intervention was $0.73(95 \% \mathrm{Cl} 0.55$ to 0.96 ) in the sterilisation group, and 0.60 ( $95 \% \mathrm{Cl} 0.46$ to $0.80)$ in the control group. The geometric mean of the ratio of the proportionate change (comparing control group with sterilisation group) in each pair of clusters was $0.829(95 \% \mathrm{Cl}$ 0.645 to $1.065 ; p=0.125$ ) indicating that gas consumption per day had reduced more in the control group than in the sterilisation group, although not statistically significantly.

There was no difference between intervention and control groups in average cold water temperatures at 2 minutes (mean difference $-0.08^{\circ} \mathrm{C}, 95 \% \mathrm{Cl}-3.24^{\circ} \mathrm{C}$ to $3.08^{\circ} \mathrm{C} ; \mathrm{p}=0.96$ ). The average cold water temperature at 2 minutes was under $20^{\circ} \mathrm{C}$ in three clusters.

There was little material difference to the results when measurements from 10 replacement households were included in the analysis: $32 \%(95 \% \mathrm{Cl} 11 \%$ to $53 \% ; p=0.007)$ reduction in prevalence of 'dangerous' and 30\% (11\% to 49\%; $p=0.007$ ) reduction in 'high' temperatures at 1 minute; $37 \%$ ( $16 \%$ to $58 \% ; p=0.003$ ) reduction in 'dangerous' maximum temperatures and $26 \%$ ( $3 \%$ to $49 \% ; p=0.03$ ) reduction in 'high' maximum temperatures.

In response to the question "How would you like your hot water?" over three-quarters of participants said that they liked their water the same as on the day of measurement, or that they didn't mind. There was no evidence for a difference in the acceptability of water temperature between the intervention and control groups (mean of cluster prevalence of satisfaction $77 \%$ in sterilisation programme group vs. $82 \%$ in control group; absolute difference $-5 \%, 95 \% \mathrm{Cl}-33 \%$ to 
$22 \% ; p=0.67)$. There was also no evidence for a differential change between baseline and followup in residents' preference for water temperature (mean of cluster prevalence of no change in preference $79 \%$ in sterilisation programme group vs. $77 \%$ in control group; absolute difference $2 \%, 95 \% \mathrm{Cl}-16 \%$ to $20 \%$; $\mathrm{p}=0.81$ ).

\section{DISCUSSION}

The results show that the thermostatic control sterilisation programme reduced the risk of scalds by achieving a 'capping' of the maximum temperature delivered to households at about $60^{\circ} \mathrm{C}$. The consistency of the hot water temperatures provided to residents was improved by the intervention halving the standard deviation of temperatures. The intervention reduced the average hot water temperature by approximately $4^{\circ} \mathrm{C}$ and there was no evidence that temperatures were less acceptable to residents. Daily gas consumption was lower in both groups following intervention (an expected seasonal change) but fuel consumption was higher in the sterilisation programme group relative to control.

The strength of this study was its randomised design, high completion of follow-up and doubleblind assessment of outcomes. The social housing estates included general residential housing and sheltered housing in a deprived inner-London borough. The properties included high-rise tower blocks and low-rise houses. The households that participated in the study included some home owners as well as council tenants. Our sampling strategy enrolled participants during the day and in the evening to ensure that a range of residents (including parents with young children, elderly, students and professionals) was represented. We have no reason to suggest that our results may not be generalised to the population living in social housing.

To our knowledge this is the first randomised controlled trial of a centralised thermostatic control system in social housing. A previous randomised trial evaluated installation of individual thermostatic mixer valves (TMV) in the homes of families with young children living in social housing.[16] The TMVs are connected to both hot and cold water supply pipes and aim to supply hot water below a maximum temperature, set on each TMV. This trial found a similar level of variation in temperatures (standard deviation $10^{\circ} \mathrm{C}$ ) at baseline as in our study. Installation of TMVs achieved a reduction in the average temperature from $61^{\circ} \mathrm{C}$ to $46^{\circ} \mathrm{C}$ and reduced the standard deviation to $0.5^{\circ} \mathrm{C}$ in the intervention households. [16] The study did not report on changes to fuel consumption. 
The marginal cost of fitting the thermostatic control system used in this study in a single boiler house is approximately $£ 4,000$. This includes the cost of equipment that is used to monitor water temperatures in boiler houses. Once installed the thermostatic control system controls the temperature of hot water supplied to all households. TMVs are available from about $£ 50$ and a qualified plumber is required to install them in each household. A future study is needed to assess the effectiveness and cost-effectiveness of centralised thermostatic control versus individual TMVs to regulate hot water temperatures and reduce scald risk in social housing.

The thermostatic control system was programmed to heat water to $65^{\circ} \mathrm{C}$ between midnight and $6 \mathrm{am}$ and to then reduce it to $50^{\circ} \mathrm{C}$ between $6 \mathrm{am}$ and midnight. The average temperature observed in our intervention households was $53^{\circ} \mathrm{C}$ which is higher than levels recommended for safety. Adjustment is therefore needed to the thermostatic control sterilisation programme to ensure that hot water is supplied at the intended $50^{\circ} \mathrm{C}$ in future.

In theory, we would have expected lower energy consumption by the boilers in the sterilisation programme group than in the control group. For example, to heat 1 litre of water from $30^{\circ} \mathrm{C}$ to each temperature recorded in households at follow-up would have required around $7 \mathrm{MJ}$ in the 73 intervention households compared to $8 \mathrm{MJ}$ in the 67 control households. However, we observed relatively higher daily gas consumption with the sterilisation programme, which may be due to differences in boiler efficiency or the number of times boilers fired (we did not match boiler houses for age and type of boilers). The sterilisation programme halved the standard deviation of hot water temperatures delivered to households, and so provision of hot water to households at more consistent temperatures might require more energy. In an in-depth investigation into attitudes and behaviours of participants regarding hot water, consistently hot water was one of the main preferences of households.[17] It may be acceptable for residents that hot water is supplied at a lower temperature provided that it is done so consistently. The extent to which tenants would be prepared to pay more for such a service remains open to question.

This study has demonstrated that it is technically feasible to regulate centrally provided hot water so that those living in social housing are not exposed to dangerous hot water temperatures, whilst a local authority maintains its duty to protect tenants from Legionella in the water system. We did not specifically test for Legionella in the water system as part of this study, 
however the London Borough of Camden routinely tests samples from water systems and no active growth was found on any study site in 2009.

\section{GUARANTOR}

Phil Edwards

\section{AUTHORS AND CONTRIBUTORS}

$P E, I R, J G, M A D, M H, S L$ and $A K$ designed the study. MAD managed the data collection and fieldwork. PE conducted the data analyses. PE, MAD, IR and JG interpreted the results. PE and MAD wrote the first draft of the manuscript. IR, JG, AK, SL and MH commented on the draft and contributed to the final manuscript.

\section{ETHICAL APPROVAL}

Ethical approval for the study was obtained from the London School of Hygiene \& Tropical Medicine Research Ethics Committee.

\section{COMPETING INTERESTS}

All authors have completed the Unified Competing Interest form at:

www.icmje.org/coi disclosure.pdf

(available on request from the corresponding author) and declare: no support from any organisation for the submitted work; no financial relationships with any organisations that might have an interest in the submitted work in the previous three years, no other relationships or activities that could appear to have influenced the submitted work.

\section{FUNDING AND ROLE OF THE STUDY SPONSOR}

This work was undertaken by the London School of Hygiene \& Tropical Medicine who received funding from Camden Primary Care Trust (PCT). AK was Director of Public Health at Camden PCT at inception of the study and assisted with study design and writing of the report. He is currently employed by the Health Protection Agency as Director of Public Health Strategy. The views expressed in the paper are those of the authors and do necessarily represent those of Camden PCT or the Health Protection Agency. Camden PCT had no role in data collection, data analysis, or data interpretation. 


\section{ACKNOWLEDGEMENTS}

We wish to thank the Camden housing residents who participated in this study for their time and for letting us into their homes to measure their water temperatures. In addition we wish to thank research assistants Mr llias Mahmud, Ms Sarah Milton, Mr Mohammad Hossain and Ms Annik Sorhaindo for their help with fieldwork and data management. Professor Richard Hayes provided advice on statistical analysis. We also wish to thank Dr John Lee for providing advice on Legionella, and three reviewers whose comments helped to improve the manuscript.

\section{TRIAL REGISTRATION}

This study is registered as ClinicalTrials.gov ID: NCT00874692.

\section{WHAT IS ALREADY KNOWN ON THIS TOPIC}

- Water temperatures over $60^{\circ} \mathrm{C}$ kill Legionella in water systems but increase the risk of scalds in young children

- Thermostatic mixer valves and educational leaflets are effective in reducing bath hot tap water temperature and are acceptable to families

- Central thermostatic control, unlike mixer valves, does not require modifications in individual households

\section{WHAT THIS STUDY ADDS}

- A central thermostatic control sterilisation programme can reduce risk of scalding in social housing by capping the maximum hot water temperature delivered to households

- With 4 million UK households living in social housing, the intervention could save lives and reduce hospitalisations of those most vulnerable to thermal injury 


\section{REFERENCES}

1. Department of Health. Hospital Episode Statistics http://www.hesonline.nhs.uk/Ease/servlet/ContentServer?sitelD=1937\&categoryID=207 (accessed 29 December 2010).

2. Han RK, Ungar WJ, Macarthur C. Cost-effectiveness analysis of a proposed public health legislative/educational strategy to reduce tap water scald injuries in children. Inj Prev 2007; 13:248-253.

3. Office for National Statistics. Mortality statistics cause, Review of the Registrar General on deaths by cause, sex and age, in England and Wales, 2005. Series DH2 no.32. ONS, London 2006.

4. Diller KR. Adapting adult scald safety standards to children. J Burn Care Res 2006;27:314-322.

5. Wickramaratne $\mathrm{H}$, Beasley $\mathrm{S}$. Legionnaires' disease and the risk of burns in children. $N Z \mathrm{Med} J$ 2008;121:U2911.

6. Feldman KW. Help Needed on Hot Water Burns. Pediatrics 1983;71:145-146.

7. Yeoh C, Nixon J, Dickson W, et al. Patterns of scald injuries to children in the bath. Arch Dis Child 1994;71:156-158.

8. Alden NE, Bessey PQ, Rabbitts A, et al. Tap water scalds among seniors and the elderly: socioeconomics and implications for prevention. Burns 2007;33:666-699.

9. Department for Communities and Local Government. English Housing Survey: Headline Report 2008-09. London: DCLG, 2010.

10. Health and Safety Executive. Legionnaires' Disease: The control of legionella bacteria in water systems. Approved Code of Practice and Guidance L8, 3rd Edition. Wales: Health and Safety Executive, Caerphilly, 2000.

11. World Health Organisation. Legionella and the prevention of legionellosis. Switzerland: WHO Geneva, 2007.

12. Dennis PJ, Green D, Jones BPC. A note on the temperature tolerance of Legionella. J Applied Bacteriology 1984;56:349-350.

13. Schulze-Röbbecke R, Rödder M, Exner M. Propagation and killing temperatures for Legionella. Schriftenr Ver Wasser Boden Lufthyg 1987;72:83-89.

14. Hockey R. Safe tap water and the risk of scalds and legionella infection. Inj Prev 2002;8:170.

15. Hayes R, Moulton LH. Cluster randomised trials. Chapman \& Hall/CRC (Boca Raton) 2009.

16. Kendrick D, Stewart J, Smith S, et al. Randomised controlled trial of thermostatic mixer valves in reducing bath hot tap water temperature in families with young children in social housing. Arch Dis Child 2010. doi:10.1136/adc.2009.175059. 
17. Durand MA, Green J, Edwards P, et al. Some like it hot - dynamics and barriers to scald prevention. Report to Camden Primary Care Trust. London: London School of Hygiene \& Tropical Medicine, 2010. 
Figure 1 Trial profile

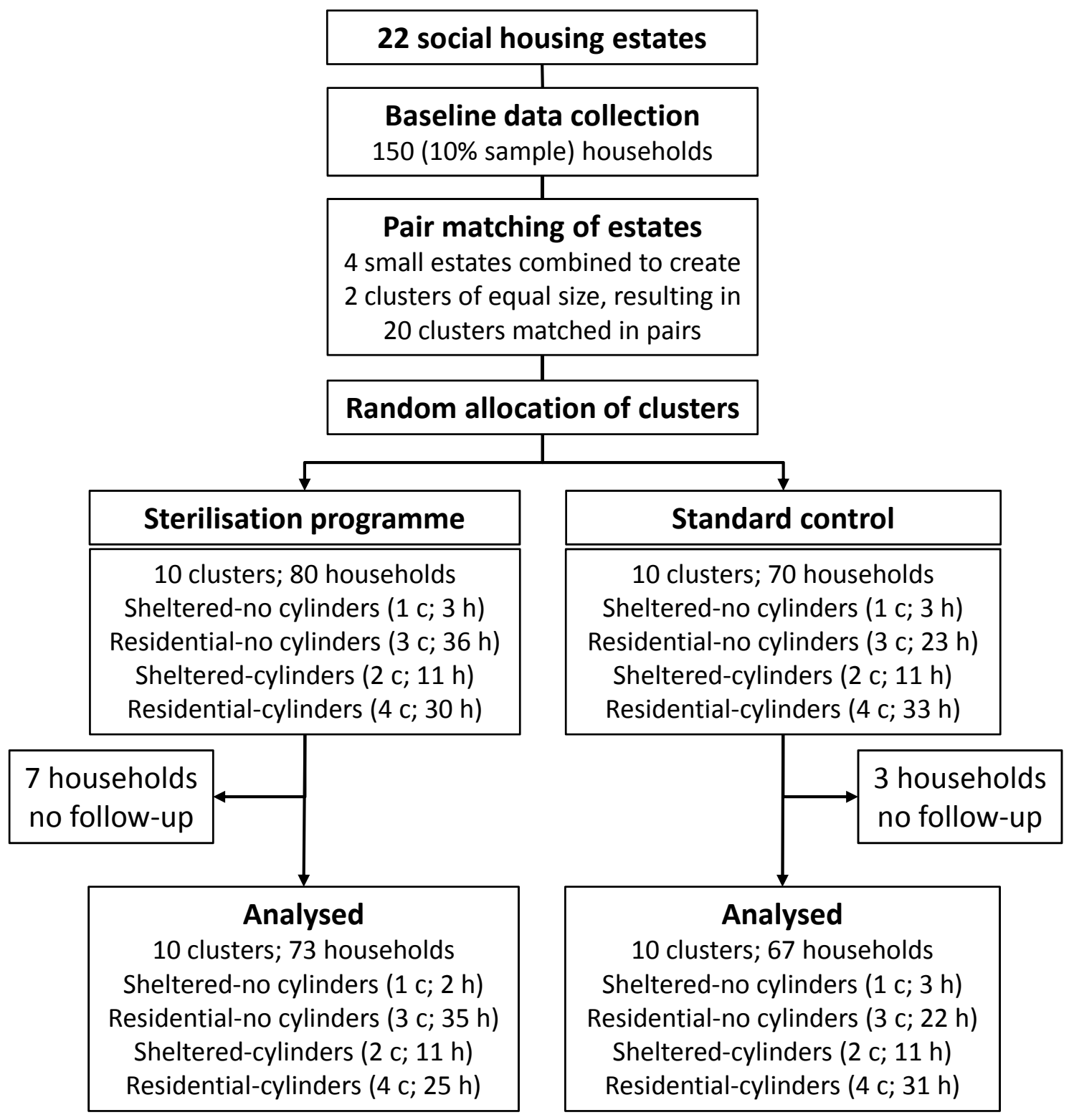


Figure 2 Hot water temperature at 1 minute at baseline and follow up (140 households)

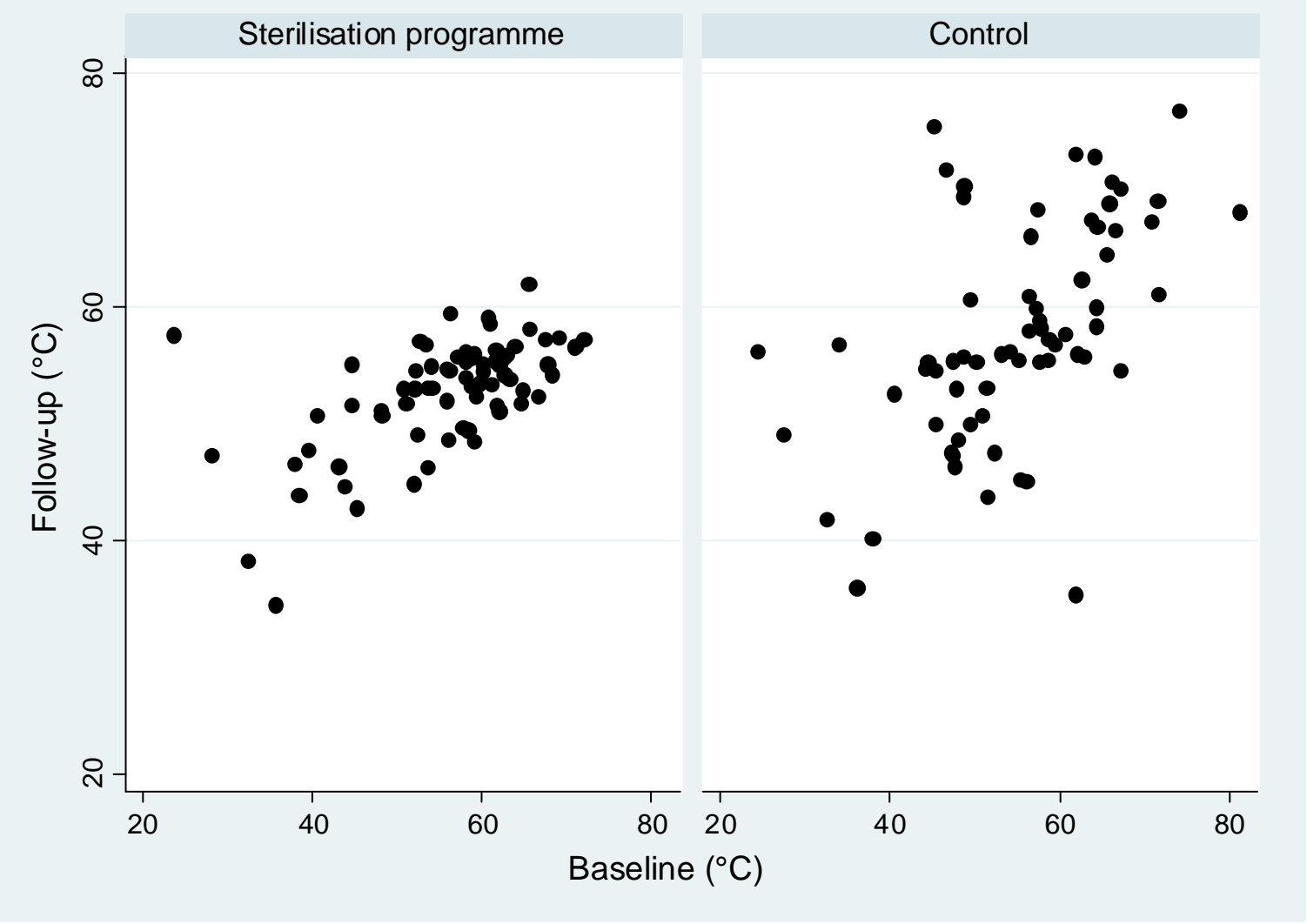

